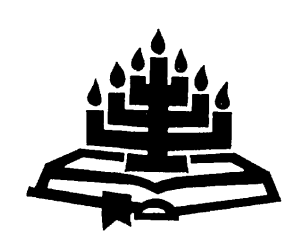

\title{
Die plek van jeugbediening binne gemeenteopbou
}

\author{
J.A. Erasmus \& B.J. de Klerk \\ Skool vir Kerkwetenskappe \\ Potchefstroomse Universiteit vir $\mathrm{CHO}$ \\ POTCHEFSTROOM \\ E-pos: jannie.erasmus@iway.na \\ kwsbjdk@puknet.puk.ac.za
}

\begin{abstract}
The place of youth ministry within congregation building

In this article perspectives on the unique subject, object, aim and nature of youth ministry and of Reformed congregation building are given. By comparing and integrating different perspectives it is determined what place youth ministry should occupy in the process of congregation building.

Opsomming

Die plek van jeugbediening binne gemeenteopbou

In hierdie artikel word perspektiewe op die unieke subjek, objek, doel en wese van jeugbediening en van Gereformeerde gemeenteopbou gegee. Deur middel van vergelyking en integrasie van die verskillende perspektiewe word bepaal wat die plek van jeugbediening binne die proses van gemeenteopbou behoort te wees.
\end{abstract}

\section{Inleiding}

Die oogmerk van hierdie artikel is om die eiesoortige en unieke wese en doel van jeugbediening te stel - teenoor en langs die wese en doel van gemeenteopbou. Hieruit sal bepaal kan word hoe jeugbediening binne die breë opbouproses van die gemeente geïntegreer moet word.

- Eerstens word vanuit die Skrif, volgens gereformeerde hermeneutiese beginsels en uitgangspunte, perspektiewe verkry oor die subjek, objek, doel en wese van jeugbediening. Ook sal resente wetenskaplike besinning oor dieselfde onderwerp betrek word om aan te toon wat die subjek, objek, doel en wese van jeugbediening is. 
- In die tweede plek sal kennis geneem word van wat die huidige navorsing as die subjek, objek, doel en wese van gemeenteopbou sien.

- In 'n gevolgtrekking sal al die inligting saamgevat en geïntegreer word om te bepaal wat die plek van jeugbediening binne gemeenteopbou is.

\section{Perspektiewe oor jeugbediening}

\subsection{Die subjek van jeugbediening}

\subsubsection{Die ouer}

In die Ou Testament vind ons veral in Deuteronomium 6 lig oor die plek wat die kind binne die volk van die Here gehad het. Wat die bediening aan die jeug betref, is dit uit Deuteronomium 6 baie duidelik dat die ouer die subjek van hierdie bediening is. In Deuteronomium 6:7 kry die ouer eksplisiet die opdrag om gedurigdeur die wet van die Here by sy kinders in te skerp - wanneer hulle op pad is, wanneer hulle by die huis is, wanneer hulle gaan slaap en wanneer hulle opstaan. Wright (1997:219220) wys daarop dat die opdrag aan ouers om hulle kinders op te voed al aan Abraham in Genesis 18:18-19 gegee is. Hierdie opdrag word in Deuteronomium voortgesit en sou dien as versekering van die volgehoue besit van die beloofde land.

Op talle ander plekke in die Ou Testament (byvoorbeeld Jos. 4:21; Ps. 78:4-7; Joël 1:3) kry die volk die opdrag om hulle kinders te vertel van die wyse waarop die Here hulle uit Egipte gelei, in die woestyn beskerm en in die beloofde land ingelei het. Niks is van meer belang vir die toekoms van God se volk as om die jeug volgens God se wil op te voed nie (Christensen, 1991:143-144).

In die Nuwe Testament kan die kind op grond van die verbondsverhouding nie los van die ouer gesien word nie. Net soos in Efesiërs 6, word 'n huistafel (O'Brien, 1982:214-215) in Kolossense 3 aangetref waar die verhouding tussen kind en ouer gereël word. Die verhouding tussen ouer en kind moet in die Here wees. Dit beteken dat sowel die ouer as die kind hulle in die verhouding onder die koningskap van Christus moet stel (O'Brien, 1982:219). O'Brien (1982:225-226) sê dat Kolossense 3:21 die ouers herinner dat hulle opvoeding werklik opbouend moet wees en die kind nie moedeloos moet maak nie. Hy noem dan dat die positiewe teenpool in Efesiërs 6:4 gegee word waar ouers aangemoedig word om hulle kinders te lei in die tug en vermaning van die Here. 
Hendriksen (1972:262-263) maak oor Efesiërs 6:4 die insiggewende opmerking dat die kind in die geloofsgemeenskap in die eerste en belangrikste plek aan die sorg van die ouer toevertrou is. Die korrekte opvoeding van kinders neem so 'n belangrike plek in dat die Here dit in 1 Timoteus 3:4 en Titus 1:6 selfs medebepalend maak om die vader vir kerklike dienswerk te keur (GKSA, 1985:493).

Net so stel Van't Zand (1995:99-100) dit dat die ouers die belangrikste rol speel in die bediening van die jeug. Die ouers is, onder leiding en toesig van die besondere dienste, die belangrikste bemiddelaars van God se verbondsgenade. Fields (1998:254) sê dat die rol van die ouers in die geloofsopvoeding van die kind deurslaggewend is. Die ouers het die hoofverantwoordelikheid vir die geestelike groei en ontwikkeling van hulle kinders.

Raubenheimer (1997:49) toon vanuit die praktyk dat die optrede van die jeug 'n spieëlbeeld behoort te wees van die waardes wat die ouers aanhang. Hieruit is dit duidelik dat die optrede van die kinders 'n spieël behoort te wees van die verhouding tussen die ouer en God.

\subsubsection{Die kerk}

Alhoewel Moses hom in Deuteronomium 6 spesifiek tot die ouers rig, is hy tog besig om met die hele volk te praat. Die hele volk kry die opdrag om die jeug in die vrees van die Here groot te maak (O'Connell, 1997:197). Christensen (1991:145) toon die pedagogiese doelwit van Deuteronomium ten opsigte van die voortdurende religieuse opvoeding wat in Israel moes plaasvind. Die hele volk moes mekaar bystaan in die uitvoering van die opvoeding van die jeug.

Lincoln (1990:241-242; 264) wys in sy kommentaar op Efesiërs 4 daarop dat die eenheid van die kerk soos dié van 'n liggaam gesien moet word. In die liggaam het Christus aan elke lid gawes gegee en die totaal van die gekombineerde gawes het as uiteindelike doel die opbou van die hele liggaam. Waar daar reeds bepaal is dat die jeug dus die verantwoordelikheid van elke lid in die kerk is, kom die opdrag nou aan elke lidmaat van die kerk om sy gawes ook tot opbou van die jeug aan te wend.

Nel (1998:101) maak die opmerking dat die jeug ook medewerkers in die jeugbediening is, want jeugbediening is ook ' $\mathrm{n}$ bediening met en deur die jeug. Die uitgangspunt hieragter is dat kinders van gelowiges self ook ingeskakel is in die handelinge van God met mense. Net soos elke ander lid van die verbondsvolk moet die jeugverbondslede luister na die opdrag van die Here en 'n bydrae lewer tot die opvoeding van ander jongmense 
in die kerk. Raubenheimer (1997:49) sê ook dat die jeug self 'n verantwoordelikheid het om as agente van verandering op te tree.

Vanuit 'n ander hoek gesien, toon Van't Zand (1995:95-100) deur Skrifstudie dat die eintlike subjek van jeugbediening die Drie-enige God, in Christus deur die Heilige Gees is. Vir die orde en bediening van die Woord in die gemeente, stel Hy besondere dienste (predikant, ouderling en diaken) in om aan die jeug hierdie versoening te bedien. Die aard van elkeen van hierdie besondere gawes sal die tipe besondere dienswerk van die predikant, ouderling en diaken bepaal.

Lincoln (1990:241) wys daarop dat die Here ook gawes aan elke gelowige (volwassenes en jongmense) gegee het om as herders vir mekaar op te tree. Fields (1998:254) en Van't Zand (1995:95-100) noem dat die eis van God nie is dat die ouers hulle geestelike verantwoordelikheid teenoor hulle kinders na die kerk oorskuif nie. Die opdrag wat wel aan die kerk gegee word, is dat die kerk die ouers moet bystaan in die geestelike ontwikkeling van hulle kinders.

\subsubsection{Gevolgtrekking oor die subjek van jeugbediening}

In die Ou Testament is dit uit Deuteronomium 6 duidelik dat die subjek van jeugbediening die ouer is - aan wie die kind as gawe toevertrou is (Nel, 1998:109). Dieselfde beginsel geld uit die Nuwe Testament, waar die korrekte wyse waarop die vader sy kinders opgevoed het, selfs as voorwaarde vir kerklike dienswerk geld. Ook hedendaagse skrywers soos Fields (1998) en Van't Zand (1995) beklemtoon die onmisbare hoofrol wat die ouers in die bediening van die jeug speel.

Die verbondsvolk van die Here (die kerk) kry egter in sy geheel die opdrag om die jeug volgens die wil van die Here as lede van sy versoende gemeenskap op te voed. Die hele volk (insluitende die jeug) kry die opdrag om mekaar by te staan en te help. Hierdie rol is egter aanvullend tot die opvoeding wat die ouer verskaf (Fields, 1998:254).

\subsection{Die objek van jeugbediening}

\subsubsection{In die Ou Testament}

Die kind is die objek van sorg wat God aan ouers toevertrou het (Nel, 1998:109; Wenham, 1994:244). Die woord wat in Deuteronomium 6 met kind vertaal is, is 7 . Hierdie woord wat meestal as seun vertaal word, kan ook vertaal word met afstammeling. Ouderdom word nie noodwendig aan hierdie woord gekoppel nie. Hiermee word die verwantskap gestel wat tussen die ouer en die kind bestaan (Caragounis, 1997:671677). In die konteks van Deuteronomium 6 is dit egter duidelik dat die 
ouers die plig het om hulle afstammelinge, terwyl hulle opgroei, te leer om die Here lief te hê en te gehoorsaam. Die opdrag geld veral vir die tyd wat die afstammeling nog by sy ouer in die huis is (Deut. 6:7-8).

'n Ander woord wat ook in die Ou Testament gebruik word om jong-

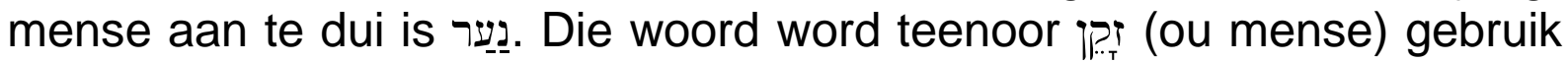
om jongmense aan te dui. Die jongmense wat met נַעַר ingesluit word, kan 'n kind van verskeie leeftydsgroepe wees: 'n kind wat net gebore is (1 Sam. 4:21), 'n drie-maande-oue babatjie (Eks. 2:6), 'n kind wat pas gespeen is (1 Sam. 1:24), 'n sewentienjarige jongman (Gen. 37:2) en selfs 'n dertigjarige (Gen. 41:12; vgl. v. 46). Hamilton (1997:125) kom tot die gevolgtrekking dat hierdie woord enige jongmens kan aandui, vanaf babastadium tot voor huweliksluiting. Die Bybel is nie ingestel op die fyn moderne onderskeid tussen die verskillende leeftydsfases nie. Wanneer die Skrif dus riglyne gee ten opsigte van kinders of jongmense, dui dit meestal op algemene beginsels wat waar is van alle verbondskinders, ongeag ouderdomme (Van't Zand, 1995:102).

In Psalm 119:9 word die vraag gestel hoe 'n يֵַַ sy lewe kan skoonhou. Die antwoord wat gegee word, is om getrou te bly aan die Woord van die Here. Wanneer die jongmens die Woord van die Here getrou ondersoek, sal daardie kennis hom in staat stel om weg te bly van 'n sondige lewe (Leupold, 1961:825). Averback (1997:1099) toon dat Psalm 119 verkondig dat die Here 'n mens lei op die pad weg van die sonde. Daarom dat die Woord van die Here ernstig ondersoek moet word. Die נַעַר moet homself ook toewy om tot kennis van die Here te kom (Da Silva, Human, Prinsloo, Botha \& Potgieter, 1999:689).

In die lig van Deuteronomium 6 is dit duidelik dat die volk in die breë, en die ouers in die besonder, die נַעַר moet begelei op die pad van toewyding aan die Here en om tot kennis van die Here te kom.

\subsubsection{In die Nuwe Testament}

In die tyd waarin die Nuwe Testament geskryf is, het die kind 'n geringe plek in die samelewing beklee en nie veel sosiale status geniet nie (Du Plessis, 1997:324; Groenewald, 1981:115). In Christus het daar 'n verruiming gekom in die siening van kinders (Van Aarde, 1991:707). In twee van Paulus se briewe, Efesiërs (6:1) en Kolossense (3:20), word kinders in die besonder aangespreek. Dit volg nadat hy die geadresseerdes van die brief as "al die heiliges" (Ef. 1:1) en "die heilige en gelowige broeders" (Kol. 1:2) aangespreek het. Hieruit kan afgelei word dat kinders deel van hierdie "heilige en gelowige broeders" is en daarom 'n onmisbare deel van die gemeente uitmaak (GKSA, 1985:495-496). 
Die begrip jeug soos ons vandag die begrip ken, kom nie in soveel woorde in die Skrif voor nie. Verskeie Griekse woorde druk in die Nuwe

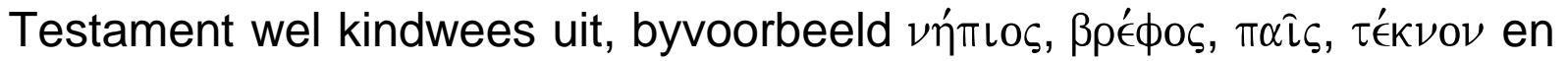
viós (Brown, 1986:280-281). Louw en Nida (1988:110) toon aan dat $\pi \alpha \hat{\imath} \varsigma$ na 'n jong persoon verwys wat nog nie puberteit bereik het nie. Nímı verwys na 'n klein kindjie wat ouer is as 'n hulpelose babatjie, maar tog nie ouer as drie of vier jaar nie. Bpé $\phi o s$ is weer 'n pasgebore, pap babatjie (Louw \& Nida, 1988:110).

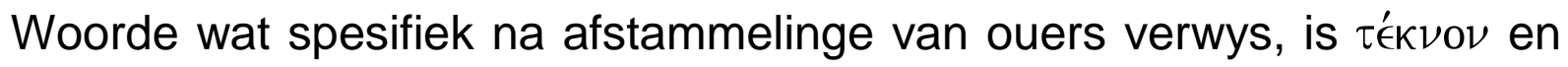
viós. T'́́kvov kan verwys na 'n seun of dogter maar viós verwys alleen na

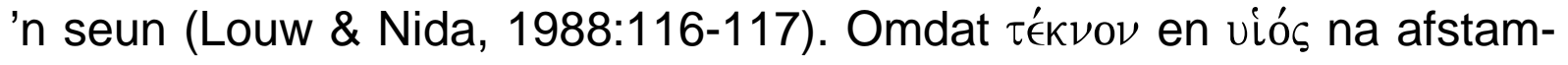
ming verwys, kan 'n spesifieke ouderdom nie aan die woorde gekoppel word nie en kan hulle ook op volwasse mense dui. Wanneer Paulus in Efesiërs 6:1 en Kolossense 3:20 sy opdrag aan kinders gee om hulle ouers te gehoorsaam, dan is die woord waarmee hy die kinders

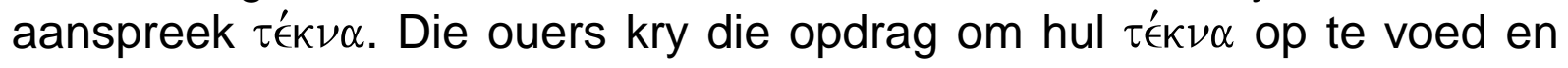
nie moedeloos te maak nie.

lets wat onthou moet word, is dat jongmense in die Nuwe Testament, net soos in die Ou Testament, vroeg al die eise van die volwasse lewe op hulle geneem het. Op twaalf jaar is 'n Joodse kind nie meer as 'n kind gereken nie, maar as 'n seun wat godsdienstig volwasse genoeg was om voortaan in grootmensgeselskap te mag verkeer (GKSA, 1985:496). Die normale tyd waarop meisies verloof kon raak, was vanaf twaalf en 'n half jaar. Jongmans het meestal tussen sewentien en drie en twintig verloof geraak (Du Plessis, 1997:317). Enersyds bied die Skrif dus die lig dat die "jeug" reeds vroeg in jare die verantwoordelikhede van die volwasse lewe op hulle moes neem, andersyds word van die "jeug" as jong volwassenes gepraat (GKSA, 1985:496).

Daar is dus 'n eenheid tussen die Ou Testament en Nuwe Testament se beskrywings oor bediening aan die jeug. Die Skrif gee algemene beginsels wat vir die jeug in die breedste sin of vir jongmense van alle ouderdomme geld.

Van't Zand (1995:103-104) toon aan dat die bediening van die jeug, alhoewel dit primêr op die verbondsjeug gerig moet wees, ook op die jeug buite die gemeente gerig moet wees. Die breë bediening in die gemeente is immers op die gelowiges gerig en deur hulle op die hele wêreld. Deur die dienswerk van die gelowige jeug en volwassenes moet jeugbediening uitreik na die wêreld. 


\subsubsection{Gevolgtrekking oor die objek van jeugbediening}

Dit duidelik dat die objek van jeugbediening die kind/jongmens binne die verbondsraamwerk is. Die kind/jongmens word gesien as integraal deel van die gesin (wat op sy beurt weer deel van die verbondsvolk van die Here is) en word juis vanuit die gesin bedien. In die ouerhuis moet die kind/jongmens die Here leer liefkry (Deut. 6:5) en so in gehoorsaamheid aan die Here, as deel van sy volk leef.

Die opdrag aan die verbondsvolk is om toe te sien dat die ouers hulle opdrag uitvoer en, waar moontlik, die ouers te help. Hierdie opdrag maak ook deel uit van die opdrag van ons Here Jesus Christus om sy Woord oor die hele wêreld uit te dra. Die buitekerklike jeug kan daarom ook as sekondêre objek van jeugbediening gesien word.

\subsection{Die doel van jeugbediening}

Die taak van jeugbediening is volgens Deuteronomium 6:5 om die verbondskinders te leer "om die Here hulle God met hart en siel en al hulle kragte lief te hê". Deuteronomium 6:6 stel dat die manier waarop hierdie liefde vir die Here gekweek moet word, daarin geleë is dat die gebooie van die Here by die kinders ingeskerp word. Die gebooie van die Here moet dan gedurigdeur op jou hart wees (עַל-לְברבקך).

Die dominante betekenis van לבָָ is is die innerlike (fisiese en geestelike) van die mens (Luc, 1997:749). As geestelike innerlike van die mens kan

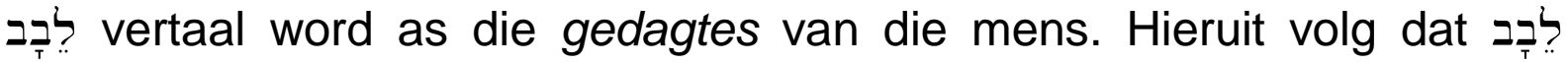
soms vertaal word as die redenasiesentrum (1983-Vertaling van Deut. 6:6), én soms as die gevoelsentrum (1953-Vertaling van Deut. 6:6). Die לרבי לב is die sentrum van emosies, gevoelens en redenasie. Selfs die kere wat die hart as redenasiesentrum genoem word, is die gevoelselement tog inbegrepe in die woord. Redenasies word immers deur gevoelens gestimuleer. Thompson (1974:122) stel dat die hart in antieke Hebreeuse psigologie as die sentrum vir die gedagtes sowel as die sentrum vir allerlei emosies gesien is.

Hieruit kan afgelei word dat die wet van die Here gedurigdeur in die gedagtes, én die emosies én die gevoelens van die kind van God teenwoordig moet wees. Die omgang met die gebooie van die Here kan nie kil en klinies wees nie. Deur passievolle omgang met die gebooie van die Here kry die kind sy God lief.

In die Nuwe Testament maak Paulus in die brief aan die Efesiërs bekend dat God se doel met die redding van gelowiges is dat hulle uit dankbaarheid vir hulle redding goeie dade van dankbaarheid moet doen (J. van Rensburg, 1999:1571). Roberts (1990:62) toon aan dat God in 
Christus gelowiges as 'n nuwe skepping byeenbring om vir Hom te lewe en nuttige werk vir Hom te verrig op die lewenspad wat Hy vir hulle gereed gemaak het.

Uit die gemeenskap met God vloei ook voort die gemeenskap met mekaar waarin samewerking tussen alle gelowiges (volwassenes sowel as die jeug) die liggaam van Christus kragdadig opbou (vgl. Ef. 4:1-16). Daarom dat Snyman (1994:139) sê dat geestelike volwassenheid die doel van jeugbediening is.

Fields (1998:17) is van mening dat die doel van jeugbediening is om die doelwitte wat God vir die kerk daargestel het, na te jaag. Hierdie doelwitte is die Groot Gebod (Matt. 22:37-39) en die Groot Sendingopdrag (Matt. 28:19-20). Wanneer dié doelwitte bereik word, is die kerk werklik kerk en word die wil van God gehoorsaam.

Nadat Raubenheimer (1997:49-60) die samelewingstoestande waarbinne die jeugondersoek funksioneer het, kom hy tot die gevolgtrekking dat jeugbediening onder andere die volgende doelwit het: om die jeug binne die gesinsopset te begelei tot die vestiging van 'n eietydse geloofsidentiteit binne die konteks van 'n veranderende gemeenskap.

Nel (1998:63-66) stel dit duidelik dat jeugbediening ingebed is in die meer omvattende konsep van gemeentebou. Die doel van God met die gemeente is die doel van God met die jeug as wesenlike deel van die gemeente (Nel, 1998:64). Jeugbediening vind plaas aan, met en deur die jeug. Wat in gemeenteopbou plaasvind ten opsigte van ouer persone, móét ook ten opsigte van die jonger lidmate gebeur. Daarom dat die doel van jeugbediening volgens Nel (1998:67) daarin geleë is dat die jeug daartoe gelei word om die Koninkryk van God in hulle lewens te laat vergestalting vind as persoonlike sowel as openbare godsdiens.

\subsubsection{Gevolgtrekking oor die doel van jeugbediening}

Die doel van jeugbediening moet wees om die kind/jongmens te leer om die Here lief te hê en voluit as volwassene in die geloof in 'n lewende verhouding met Hom te staan. Hierdie doel kan bereik word deur die kind op bevatlike wyse te onderrig in die versoening wat God deur Christus vir sy verbondsvolk - en die kind self as lid van die verbondsvolk - berei het.

Wat in die gemeente gebeur, moet terselfdertyd met die jeug as onmisbare deel van die gemeente gebeur. Die jeug moet gelei en begelei word om as deel van 'n gemeente wat 'n verskil maak, in die wêreld waarbinne hulle leef, op te tree en so die wil van God te gehoorsaam. 
Die Bybelse doel van jeugbediening word kernagtig opgesom in Spreuke 22:6 waar gestel word: "Gee leiding aan 'n jongmens oor hoe hy moet leef, en hy sal ook as hy al oud is nie daarvan afwyk nie."

\subsection{Die wese van jeugbediening}

Omdat die kind in jeugbediening begelei word tot 'n lewende verhouding met God is jeugbediening in wese Woordbediening (Van't Zand, 1995: 97). Uit Deuteronomium 11:13 is dit duidelik dat God opdragte aan sy volk gee oor hoe hulle hierdie lewende verhouding in liefde moet uitleef (Van Rooy, 1999:208-209). Vanuit hierdie liefde tot God word in Deuteronomium 6 aanduidings gegee van hoe die ouer passie en liefde vir God by die kind moet ontwikkel:

- In Deuteronomium 6:7 gee Moses die opdrag dat die ouer gedurigdeur met die kind moet praat en die kind die gebooie van die Here moet leer (Van Rooy, 1999:205).

- Die ouer skerp egter ook die gebooie van die Here in deur as model die gebooie uit te lewe. In Deuteronomium 6:20 vra die seun nie wat die gebooie van die Here is nie, hy vra waarom hulle die gebooie nakom - die seun weet wat die gebooie is en hy sien hoe sy ouer dit gehoorsaam. In sy kommentaar oor Efesiërs 6:4 stel Bruce (1984: 398-399) dat kinders baie makliker lesse van hulle ouers leer wanneer hulle ouers aan hulle die pad toon deur lewensvoorbeeld.

Nel (1998:110) verduidelik hierdie modelleringsbeginsel deur daarop te wys dat 'n mens veral deur waarneming en modellering leer. Die kind kyk na sy ouers vir geloofsmodellering. Langtermyn-nabyheidsverhoudings verhoog die impak van modellering omdat kinders die ouers moet leer verstaan. Dit beteken dat ouers moet leer om hul geloof in God in verband te bring met die gebeure van elke dag (Nel, 1998:110-112).

In die Nuwe Testament vind ons dat buiten die ouerhuis, onderrig ook by sinagoges en onder leiding van leermeesters plaasgevind het. Leerlinge het aan die voete van hul leermeesters gesit (vgl. Hand. 22:3) en deur herhalingstegnieke en gelykenisse is sekere wetspunte verduidelik en geïllustreer (Du Plessis, 1997:325-326). Vanuit hierdie hoek gesien, is jeugbediening dus didache (Nel, 1999:31).

Nel (1999:31) stel dit egter duidelik dat, in die lig van die eenheid en verweefdheid van jeugbediening met ander bedieningsmodi in die kerk, jeugbediening nie uitsluitlik onder didache kan verstaan word nie. In 'n vroeëre publikasie van $\mathrm{Nel}$ (1998:88-95) het hy aangetoon hoe jeugbediening normale bediening aan, met en deur die jeug is, deur middel van al die bedieningsmodi wat in die opbou van die gemeente ter sprake 
is. Daarom dat Fields (1998:18) sê dat jeugbediening in wese die toerusting van jongmense is om 'n lewende geloof in die midde van die gemeente uit te leef.

Uit die voorafgaande het dit duidelik geword dat die toerusting van jongmense geïntegreerd binne die opset van die verbondsgemeenskap moet plaasvind. Die kind staan nie buite die verbondsgemeenskap nie en is voluit in God se verbond ingesluit (Van't Zand, 1995:109; Van Aarde, 1991:693).

Omdat kinders volledig deel van die gemeente is (GKSA, 1985:495-496), deel hulle volledig in die opbou van die gemeente. Daarvoor het elke lidmaat (insluitende elke kind) 'n gawe van die Here ontvang (Bruce, 1984:339-340) en moet die gawes gebruik word om die liggaam van Christus op te bou (Lincoln, 1990:241).

Nel (1998:88) noem dat, alhoewel jeugbediening integraal deel van gemeentewerk is, daar tog gedifferensieer moet word omdat daar 'n verskil is of iemand tien of vyftig is. So gesien, is jeugbediening niks anders as die normale bedieninge nie, maar geskied dit met inagneming van die bedieningseie en die jeugeie. Richards en Bredfeldt (1998:93-94) sê dat bediening nie kan plaasvind indien die behoeftes en belangstellings van die mense wat bedien word (jongmense), nie begryp en in die bediening verreken word nie.

Enkele faktore wat die behoeftes en belangstellings van jongmense in Suid-Afrika vandag beïnvloed, is die volgende:

Wat breër samelewensfaktore betref, het die Konvent van Reformatoriese Kerke in Suider-Afrika (1999:8-9) die volgende tendense in die Suid-Afrikaanse samelewing onderskei:

- Geweld en misdaad is aan die orde van die dag.

- Armoede neem geweldige afmetings aan.

- Aborsie is gewettig en word op aanvraag gedoen.

- 'n Gesonde werksetiek word bepleit - hieruit kan afgelei word dat daar 'n ongesonde werksetiek onder 'n groot deel van die SuiderAfrikaanse samelewing is.

- Daar is 'n agteruitgang in mediese dienste in hospitale. Sedeloosheid en losbandigheid dra grootliks hiertoe by, omdat laasgenoemde groot druk op hierdie dienste plaas.

Die verklaring van die National Consultation of Churches in South Africa (1999:9-10) wat van 22 tot 26 Februarie 1999 te Rustenburg gehou is, 
het die volgende tendense in die Suider-Afrikaanse samelewing addisioneel uitgelig:

- Bevoorregte sowel as agtergeblewe gemeenskappe kan in SuiderAfrika onderskei word;

- Opvoeding in skole beleef 'n groot krisis.

Hieruit is dit duidelik waarom Raubenheimer (1997:57) aangetoon het dat die kerk as draer van die boodskap van hoop ernstig kennis moet neem van die volgende feite: daar is by baie jongmense 'n gees van moedeloosheid met min vreugde en hoop oor die toekoms. Hulle is op pad na 'n toekoms waaroor hulle nie opgewonde is nie. Wie nie opgewonde oor môre is nie, kan nie veel erns met vandag maak nie.

Wat spesifiek geestelike werklikhede betref, word die volgende tendense onderskei: alhoewel die kerk as institusie gewantrou word, is daar 'n intense geestelike hongerte. Vanuit jongmense se postmoderne denkraamwerk besit hulle 'n relatiwistiese godsdiensbesef. Eksklusiewe religieuse aansprake (byvoorbeeld dat net mense wat in Christus glo, gered is) is vir baie jongmense (lede van Generasie $X$ ) onaanvaarbaar (Menking, 1999:157). Alle godsdienste word dikwels as ewe waar beskou en almal lei op 'n manier tot 'n mens se saligheid. Sinkretisme is dus aan die orde van die dag (Van der Walt, 2001:11).

Jeugbediening is dus 'n spesifieke bediening wat binne in die gemeente gelewer word en geloofsgroei by jongmense wat in bogenoemde omstandighede lewe, moet bevorder.

Van't Zand (1995:95) stel dat die wese van bediening die beste saamgevat word deur die Bybelse begrip $\delta\llcorner\alpha \kappa o \nu i \alpha$, wat vertaal kan word

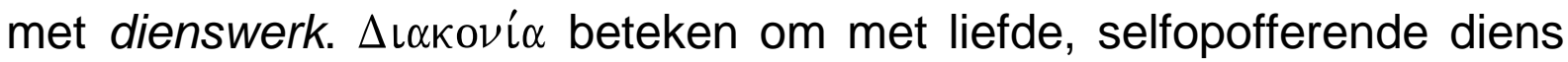
aan ander te verskaf, ander te versorg en om die gawes wat die Here aan jou gegee het, tot opbou van die gemeente te gebruik sonder die doel om jouself te bevoordeel (Hess, 1986:545-549). Die ouers en die res van die gemeente, insluitende die jeug, moet in hierdie diens, net soos in enige ander lidmaat in die gemeente, dienswerk doen, totaal toegewy wees en voluit werk vir die heil en welsyn van die jeug binne die hedendaagse samelewing.

\subsubsection{Gevolgtrekking oor die wese van jeugbediening}

Jeugbediening moet geïntegreerd met die res van die bediening in die gemeente plaasvind omdat die jeug deel is van die volk van God. So dien jeugbediening ook tot opbou van die gemeente. Tog moet op 'n 
gedifferensieerde wyse gewerk word vanweë die unieke behoeftes en omstandighede van die jeug.

Jeugbediening is in wese Woordbediening, want deur kennis van die Woord van God word die kind toegerus om God lief te hê en om as lid van die volk van God te funksioneer en so mee te werk tot die opbou van die volk van God. Hierdie toerusting vind op verskeie wyses plaas.

- By die huis en in die gemeenskap word die kind deur die ouer en deur die kerk in die Woord van God onderrig. Hierdie toerusting kan ook didache genoem word.

- Die ouers en ander gelowiges moet deur modellering aan die kind toon hoe gelowiges die Woord van die Here uitleef.

- Toerusting word ook gegee deur aktiewe dienswerk te verrig. Deur die kind (wat volledig deel van die gemeente is) volledig in die dienswerk van die gemeente in te trek en die kind op hierdie manier self te laat dien, word die kind binne die praktyk opgevoed om 'n lewe tot eer van God en tot opbou van sy gemeente te leef.

- In hierdie aktiewe dienswerk moet egter rekening gehou word met die behoeftes en voorkeure van die jeug. Kennis moet gedra, en in jeugbediening verantwoord word aangaande die besondere behoeftes wat spruit uit die ontwortelde samelewing waarin die jeug lewe en die eise wat die postmodernisme aan die jeug stel.

\section{Perspektiewe oor gemeenteopbou}

\subsection{Die subjek van gemeenteopbou}

Burger (1999:55) wys daarop dat die beelde waarmee die kerk in die Bybel uitgedruk word, baie duidelik toon dat die kerk aan God behoort. $\mathrm{Hy}$, en nie mense nie, is die Eienaar van die kerk. Daarom is Hy ook die Bouer van sy kerk en die Subjek van gemeenteopbou (vgl. Nel, 1994:4; Hendriks, 1992:40, 80; GKSA, 2000:505).

Die wyse waarop God hierdie bouwerk verrig, is deur sy Gees (Nel, 1994:19). Ook Te Velde (1992b:63-64) wys daarop dat die krag waaruit gemeenteopbou funksioneer, die krag van die Heilige Gees is. Die Gees lei die kerk tot gehoorsame beoefening van die geloofsdissiplines wat in die Woord voorgeskryf en geleer word (Burger, 1999:143; GKSA, 2000:505).

Nel (1994:19-20) en Hendriks (1992:82) gee die perspektief dat God in die proses van gemeentebou, wat vernuwing en groei insluit, van mense gebruik maak. Omdat Hy egter die inisieerder daarvan is, is gemeente- 
vernuwing nie in die eerste plek 'n menslike aktiwiteit nie. Daarom dat gesê kan word dat God in die proses van die opbou van die gemeente van mense gebruik maak as sy instrumente (Hendriks, 1992:40; GKSA, 2000:508). Die Heilige Gees doen selde sy werk sonder dat Hy mense in diens neem en middellik gebruik (Burger, 1999:161).

Te Velde (1992b:74-96) toon uitvoerig aan dat die Here besondere gawes aan sekere mense gegee het om die kerk tot opbou te lei. Hiervan is die ampte (predikant, ouderlinge en diakens) onmisbare gawes wat die Godgegewe opdrag het tot diensverlening vir die gemeente met die oog op die interne en eksterne opbou daarvan (Te Velde, 1992b:108).

\subsubsection{Gevolgtrekking oor die subjek van gemeenteopbou}

God Drie-enig is die subjek van gemeenteopbou. Hy is die een wat sy kerk uitkies, vergader, bewaar en vermeerder (Du Plooy, 1995:2). Deur sy Gees werk Hy in mense en rus hulle toe met gawes sodat Hy hulle in sy diens tot opbou van die gemeente kan gebruik. Alhoewel die mens dus ook as subjek van gemeenteopbou optree, doen die mens dit net in die hoedanigheid van 'n instrument van God.

\subsection{Die objek van gemeenteopbou}

Nel $(1994: 4,19)$ toon deur Skrifstudie dat die objek wat deur God (as subjek) gebou word, die kerk is onder wie Hy woon en deur wie Hy werk. Ook Hendriks (1992:42) sê gekwalifiseerd dat die objek van God se bouwerk sy verbondsvolk is. Die kwalifikasie lê daarin dat as die volk van God aan Hom ongehoorsaam is, Hy hulle nie opbou nie, maar afbreek.

Du Plooy (1995:2, 122-123) wys daarop dat met "kerk" twee dinge bedoel kan word. Uit die Nuwe Testament is dit duidelik dat die begrip "kerk" óf gebruik kan word om die gelowiges op een plek op 'n bepaalde tyd (die plaaslike kerk) aan te dui, óf om "die gelowiges oor die hele aarde, en ook in die hemel" omvattend (die universele kerk) aan te dui. Daarom kan gesê word dat die plaaslike kerk die vrug van die koninkryk van God is, maar ook die instrument waardeur die koninkryk verkondig sowel as verwerklik moet word. Hendriks (1992:83) is korrek wanneer hy sê dat die kerk nie 'n doel op sigself is nie, maar daar is ter wille van die koninkryk van God en God se heerskappy op elke terrein van die lewe (vgl. GKSA, 2000:509).

Die kerk is dus ' $n$ vergadering van individuele gelowiges. Wie bely dat God kerke tot vernuwing roep, moet aanvaar dat God al die gelowiges binne die kerk tot vernuwing en opbou roep. Nel (1994:15) wys daarop dat die enkelgelowige in die Bybel sterk in 'n verwantskap met die geheel 
van die gemeente funksioneer. Dit is belangrik om in te sien dat die opbou van die individuele gelowige altyd in diens van die groter geheel, die kerk, geskied. Die individuele gelowige word toegerus vir sy dienswerk sodat hy instrument van God in God se kerk en koninkryk kan wees (Hendriks, 1992:83).

Burger $(1999: 151,158)$ sê dat gemeentes nie net die werk van mense is nie, maar in die eerste plek die werk van die Heilige Gees. Dit is die Gees van God wat die kerk lei om op 'n waardige en oortuigende wyse werklik die "liggaam van Christus" te wees.

\subsubsection{Gevolgtrekking oor die objek van gemeenteopbou}

Die objek van gemeenteopbou is die gemeenskap van gelowiges wat deur die Heilige Gees saamgebind word. Hierdie gemeenskap word vergestalt in die plaaslike kerk. Omdat die kerk uit individuele gelowiges bestaan, moet opbou van die individuele gelowiges plaasvind. Hierdie opbou staan egter in diens van die groter saak - die opbou van die kerk in sy geheel.

\subsection{Die doel van gemeenteopbou}

Vir die ontstaan en bestaan van die kerk is daar maar net een doel en dit is die eer van God. Die oorkoepelende doel van die kerk - opbou en uitbou - is die eer van God. Daarom is die eer van God ten nouste verbind aan die voortbestaan en bestaan van die kerk (GKSA, 2000: 505).

Die doel waarom God die kerk opbou, is juis sodat die kerk al hoe meer word wat Hy wil hê dit moet wees (Nel, 1994:19). Tog sê Burger (1999:143) dat dit nie vir mense vanself kom om oor 'n lang tyd met God te bly leef nie. Daar bestaan 'n wesenlike gevaar vir stagnasie in mense se verhouding met die Here. Geen gemeente is reeds wat hulle kan wees en in Christus Jesus reeds is nie (Nel, 1994:20). Juis omdat God reeds en steeds besig is om sy gemeente te bou, veroorsaak enige stagnasie dat die gemeente in sy doel faal (GKSA, 2000:508). Hieruit is dit duidelik dat God sy gemeente tot verantwoordelike vernuwing roep.

Behalwe vir vernuwing is 'n belangrike doel van gemeenteopbou ook die vermeerdering en bewaring van die kerk. 'n Suiwer kerk wat besig is om te bewaar (op te bou), sal noodwendig ook besig wees om te vermeerder (uit te bou); en 'n kerk wat besig is om te vermeerder, het ook dadelik die roeping om nuwe gelowiges te leer om alles te onderhou wat die Here Jesus beveel het (GKSA, 2000:507). 
Du Plooy (1995:2) sê dat die doel van opbouwerk wat in die gemeente plaasvind, die uitverkiesende, vergaderende, bewarende en vermeerderende werk van die Drie-enige God is, deur sy Woord en Gees, en deur diegene wat Hy in sy diens daartoe geroep het. In hierdie sin is alle werk in die kerk (wat in gehoorsaamheid aan God gedoen word) dienstig aan die opbou van die kerk.

Nel (1994:10) stel dit egter duidelik dat nie alles wat tot die opbou van die gemeente gebeur, gemeentebou genoem kan word nie. Die doel wat hy vir die opbou van die gemeente sien, kan vanuit sy definisie van gemeentebou afgelei word. Daarvolgens is die doel dat die gemeente opgelei en begelei word om:

- sy eie wese en bestaansdoel te verstaan;

- self, as gemotiveerde gemeente, sy eie funksionering te evalueer, doelwitte vir sy doelgerigte funksievervulling te formuleer en op beplande wyse te bereik;

- self, soos nodig, strukture vir korrekte gemeentelike funksionering te ontwikkel (Nel, 1994:14).

Ook Du Plooy (1995:2-3) sê dat die totale bediening die gemeente moet bou, maar dat gemeentebou nie in sy totaliteit bloot alles is wat in belang van die opbou van die gemeente gebeur nie. Hieruit is dit duidelik dat die doel van gemeentebou daarin geleë is om op 'n planmatige, doelgerigte en samehangende manier (vgl. Te Velde, 1992a:52) die kerk daartoe te bring om in hierdie wêreld waarvoor God die kerk geroep het te wees. So gesien, kom die doel van die bouwerk van God deur sy kerk neer op die vorming van 'n Geesvervulde gemeenskap van dissipels van Jesus Christus (GKSA, 2000:509).

Volgens Hendriks (1992:84) is 'n doelwit van gemeenteopbou dat die gemeente 'n bolwerk teen dwaalleer moet wees. As die gemeente opgebou word, groei dit na Christus toe, na geestelike volwassenheid, en word daardie lidmate nuwe mense in wie Christus lewe. Daaruit volg dat daar ook kwantitatiewe vermeerdering van die kerk is (Hendriks, 1992:83). Kwantitatiewe opbou kan slegs plaasvind as die verbondsgemeenskap inwendig, kwalitatief opgebou word om heilige, toegewyde en toegeruste diensknegte te wees. Die gelowiges bou mekaar op en hoe meer hulle in die krag van die Gees in die lig lewe, hoe doeltreffender is hulle getuienis van die lig en hoe meer tree mense uit die duisternis toe tot die lig. Die inwendige en uitwendige opbou van die gemeente vul mekaar dus aan. 
Omdat die bestaan en groei van die kerk die totstandbring van die koninkryk van God impliseer, moet die kerk doelbewus op alle samelewingsterreine ligtende lig en soutende sout wees. Die doel van gemeenteopbou is dus ook dat die kerk 'n sterk profetiese stem in politieke, ekonomiese, veiligheid- en sosiale sake sal wees, sal uitreik na minderbevoorregtes in konkrete dade van barmhartigheid, betrokkenheid by die skep van werksgeleenthede en die opbou van die gefragmenteerde, geweldsgeteisterde samelewing van Suid-Afrika (GKSA, 2000: 509).

\subsubsection{Gevolgtrekking oor die doel van gemeenteopbou}

Die doel van gemeenteopbou is dus om op 'n planmatige, doelgerigte en gestruktureerde wyse die (plaaslike) kerk te lei om dit te wees waartoe God die kerk geroep het. So word die eer van God gehandhaaf en uitgedra. Die (plaaslike) kerk moet tot geestelike volwassenheid kom en God se opdrag van opbou en uitbou gehoorsaam. Geestelike volwassenheid word bereik deur die inwendige opbou van gelowiges om heilige, toegewyde en toegeruste diensknegte van die Here te wees. Só vorm die kerk 'n bolwerk teen dwaalleer én word profetiese getuienis in die wêreld gelewer deurdat die kerk soutende sout en ligtende lig in die wêreld is.

\subsection{Die wese van gemeenteopbou}

Du Plooy (1995:130) toon aan dat gemeenteopbou, veral in die Gereformeerde Kerke in Suid-Afrika, tradisioneel gesien is as die resultaat van effektiewe, Skrifgefundeerde bedieningsgestaltes van die Woord. In 'n volgende publikasie skryf Du Plooy en Venter (1996:357) dat naas ander bedieningsgestaltes van die Woord, die plaaslike kerk ook onder leiding van die ampte begelei word om die bouwerk van God aan sy kerk te verstaan, en daaraan mee te werk in gehoorsaamheid aan God in sy Woord.

As bogenoemde in ag geneem word, kan verstaan word waarom Burger (1999:157) sê dat, behalwe vir die gawe van die Heilige Gees, die gemeente ook daarmee rekening moet hou dat daar sekere aktiwiteite is waarvoor gemeentelede opgeroep word om te doen sodat die werk van die Heilige Gees as 't ware in hierdie wêreld gekanaliseer word. Die verantwoordelikheid rus daarom op die gemeente om alle menslik verwerfde kennis en inligting wat moontlik kan help in dienswerk in die gemeente, ernstig op te neem en te probeer gebruik (Burger, 1999:163).

Die wyse waarop die dienswerk in die gemeente verrig kan word, kom tot uiting in die handelinge van die gemeente. Hierdie handelinge wat in die 
gemeente gedoen word, vind plaas in handelingsvelde wat bestudeer moet word (Heyns \& Pieterse, 1994:15). Alhoewel verskillende skrywers verskillende indelings volg vir die indeling van hierdie handelinge, word daar tradisioneel sewe handelinge (bedieningsmodi) onderskei ( $\mathrm{Nel}$, 1994:26): kerugma (prediking), marturia (missionêre aspek), didache (onderrig), leitourgia (erediens), koinonia (gemeenskap), paraklese (sorg), en diakonia (diens).

Om hierdie bedieningsmodi in 'n gemeente te verwerklik en ' $n$ bediening gestalte te laat kry, moet bedieningsvorme geskep word. Nel (1994: $216,239)$ wys daarop dat bedieninge nie anders kan as om in bepaalde vorme/strukture te geskied nie. Die strukture is kanale wat die inhoud van die evangelie moet dra.

Dit is daarom die plig van elke lidmaat om betrokke te wees by die funksionering van hierdie bedieningsmodi in die gemeente tot opbou van die liggaam van Christus. Tog stel Erasmus en De Klerk (1999:505) dat besondere dienswerkers (die ampte) nodig is om lidmate tot funksionering in die liggaam van Christus te bring. Dit vind plaas wanneer die besondere dienswerkers die lidmate toerus om deur middel van betrokkenheid in die onderskeie handelingsvelde, die bedieningsmodi in die gemeente te laat funksioneer en sodoende meewerk in die opbou van die gemeente. Du Plooy (1995:130) maan egter dat gewaak moet word om gemeenteopbou nie te verskraal tot alleen die proses van toerusting nie. Toerusting bly slegs 'n onderafdeling van die gemeente wat besig is om homself op te bou tot die volheid van God in Christus.

Hendriks (1992:85) stel dat die gemeente opgebou word deur die dienswerk van gelowiges wat met gawes toegerus is. Hierdie dienswerk geskied in die konteks van liefde, koinonia, gehoorsaamheid, kennis, vrede, orde, vreugde, gebed, getuienis, onderrig, erediens, geregtigheid, dade van barmhartigheid en die voortgaande proses van stryd.

\subsubsection{Gevolgtrekking oor die wese van gemeenteopbou}

Die wese van gemeenteopbou is dat dit die resultaat is van effektiewe, Skrifgefundeerde bedieningsgestaltes van die Woord van God. Hierdie bedieningsgestaltes word geaktiveer deur toegeruste lidmate wat die gawes waarmee hulle deur die Heilige Gees toegerus is, tot voordeel en tot opbou van die gemeente gebruik. Opbou van die gemeente vind nie plaas deur toerusting nie, máár deur die dienswerk wat verrig word deur toegeruste lidmate. 
Hierdie dienswerk word verrig deur bedieningsvorme in die gemeente te vestig waarbinne die verskillende handelinge (bedieningsmodi) van die gemeente tot gestalte kom.

\section{Riglyne vir jeugbediening binne gemeenteopbou}

\subsection{Die subjek van jeugbediening binne gemeenteopbou}

- Die subjek van jeugbediening binne die proses van gemeenteopbou is God Drie-enig. Hy kies uit, vergader, bewaar en vermeerder sy kerk.

- Deur sy Gees roep en rus God gelowiges toe tot diens om in die opbou van die kerk mee te werk. Gelowiges is daarom instrumente van die Here wat Hy in die opbouproses gebruik.

- Ouers is die besondere instrumente wat die Here in die eerste plek gebruik om kinders en jongmense toe te rus en te begelei tot geestelike volwassenheid. Kinders word as gawes van die Here aan ouers toevertrou. Ander gelowiges mag nooit hierdie taak van die ouers oorneem nie.

- Alle gelowiges het die opdrag om mee te werk aan die opbou van die liggaam van Christus. Die hele kerk moet ouers toerus, begelei en help in die taak van die geloofsopvoeding van die kind en jongmens. Ander gelowiges mag ouers nooit alleen laat in hierdie taak nie.

\subsection{Die objek van jeugbediening binne gemeenteopbou}

- Die objek van gemeenteopbou is die liggaam van Christus - die kerk van die Here. Die universele kerk kom tot stand onder spesifieke gelowiges op spesifieke tye en op spesifieke plekke in die plaaslike kerk. Hierdie plaaslike kerk bestaan uit verskillende gelowiges van verskillende ouderdomme.

- Die objek van jeugbediening binne die proses van die opbou van die gemeente is die kinders en jongmense in die plaaslike kerk. Kinders en jongmense in die kerk is volledig deel van die liggaam van Christus en moet self begelei en toegerus word om tot geestelike volwassenheid te kom. So sal hulle self toegerus en geaktiveer word om as volwaardige lidmate van die kerk te kan deel in die opbouproses van die gemeente.

- In die opbouproses word die gemeente uitgebou en in hierdie proses word daar ook uitgereik na die jeug buite die kerk. 


\subsection{Die doel van jeugbediening binne gemeenteopbou}

- Die doel van gemeenteopbou is om die plaaslike kerk te lei tot geestelike volwassenheid en daardeur die kerk te laat funksioneer tot eer van God. Gelowiges moet op doelgerigte en gestruktureerde wyse toegerus en gelei word om toegewy en aktief met hulle gawes mee te werk in die opbouproses van die gemeente.

- In jeugbediening moet die kind en jongmens geleer en begelei word om in ' $n$ lewende verhouding met die Verbondsgod te staan. So groei die kind en jongmens self in geestelike volwassenheid en word die kind en jongmens toegerus en opgebou om te groei na Christus, die Hoof van die kerk. In dié proses werk die kind en jongmens self ook mee in die opbou van die gemeente.

- Omdat die bestaan en groei van die kerk die totstandbring van die koninkryk van God is, moet die kerk en haar lidmate (ook jeuglidmate) doelbewus soutende sout en ligtende lig wees. 'n Doelwit van jeugbediening is dus ook die toerusting van jongmense om 'n profetiese stem in 'n ontwortelde samelewing te laat hoor en deur aktiewe dienswerk die liefde van Christus uit te straal.

\subsection{Die wese van jeugbediening binne gemeenteopbou}

- Die wese van gemeenteopbou is dat alle lidmate (ook jeuglidmate) toegerus en geaktiveer word om hulle Godgegewe gawes tot voordeel en tot opbou van die kerk te gebruik. Dit is dan ook die wese van jeugbediening binne die proses van die opbou van die gemeente. So word die gemeente in die geheel, en kinders en jongmense as deel van die geheel, opgebou.

- Hierdie toerusting en aktivering van volwasse en jeuglede vind plaas deur effektiewe, Skrifgefundeerde bedieningsgestaltes van die Woord van God. Om effektief tot die kind en jongmens te kan spreek, moet gedifferensieer en rekening gehou word met dit wat leeftydseie aan die jeug is.

- Effektiewe, Skrifgefundeerde bediening van die Woord van God aan die jeug moet kontekstueel ontwikkel en moet geïntegreerd met die res van die bediening in die gemeente aangebied word. Bediening aan die jeug moet nie gesien word as ' $n$ aparte of nuwe bedieningsmodus nie. Dit gaan in jeugbediening nie daarom om 'n ekstra plek vir nog 'n bedieningsmodous te vind nie, maar om vir die jeug plek te vind binne die ruimte en tussen die mense op wie die bedieninge gerig is - die mense na wie God deur die bedieninge kom. Daar moet dus in die kerugma (prediking), marturia (missionêre aspek), didache (onderrig), leitourgia (erediens), koinonia (gemeenskap), paraklese 
(sorg) en diakonia (diens) van die gemeente doelbewus plek en ruimte vir die jongmens gevind word.

- In jeugbediening moet rekening gehou word met die konkrete werklikheid en 'n ontwortelde samelewing waarbinne die jongmens leef en hierdie werklikheid moet in die bediening verreken word.

\section{Bibliografie}

AVERBACK, R.E. 1997. זָזה (In Vangemeren, W.A., ed. New International Dictionary of Old Testament Theology and Exegesis. Vol. 1. Grand Rapids, Michigan : Zondervan. p. 671-677.)

BROWN, C., ed. 1986. New International Dictionary of New Testament Theology. Grand Rapids, Michigan : Zondervan.

BRUCE, F.F. 1984. The New International Commentary on the New Testament. The epistles to the Colossians, to Philemon, and to the Ephesians. Grand Rapids, Michigan : Eerdmans.

BURGER, C. 1999. Gemeentes in die kragveld van die Heilige Gees. Oor die unieke identiteit, taak en bediening van die kerk van Christus. Stellenbosch : BUVTON.

CARAGOUNIS, C.C. 1997. ㄲ. (In Vangemeren, W.A., ed. New International Dictionary of Old Testament Theology and Exegesis. Vol. 1. Grand Rapids, Michigan : Zondervan. p. 671-677.)

CHRISTENSEN, D.L. 1991. Word Biblical Commentary. Volume 6A. Deuteronomy 111. Dallas, Texas : Word Books.

DA SILVA, A.A., HUMAN, D.J., PRINSLOO, G.T.M., BOTHA, P.J. \& POTGIETER, J.H. 1999. Psalms. (In Vosloo, W. \& J. van Rensburg, F., red. Die Bybellennium eenvolumekommentaar. Die Bybel uitgelê vir eietydse toepassing. Vereeniging : CUM. p. 600-707.)

DU PLESSIS, I.J. 1997. Die sosiale en ekonomiese lewe van die Joodse volk in Palestina in die tyd van die Nuwe Testament. (In Du Toit, A.B., red. Handleiding by die Nuwe Testament. Deel 2. Halfway House : Orion. p. 315-336.)

DU PLOOY, J.L. 1995. Die betekenis van gemeente-opbou vir die Gereformeerde Kerke in Suid-Afrika. Potchefstroom : PU vir CHO. (Verhandeling - Th.M.)

DU PLOOY, J.L. \& VENTER, C.J.H. 1996. Gereformeerde gemeente-opbou? 'n Evaluering van bestaande definisies binne die geledere van die Gereformeerde Kerke in Suid-Afrika. In die Skriflig, 30(3):343-363.

ERASMUS, J.A. \& DE KLERK, B.J. 1999. Riglyne vir die toerusting van ouderlinge. In die Skriflig, 33(4):491-507.

FIELDS, D. 1998. Purpose driven youth ministry. Nine essential foundations for healthy growth. Grand Rapids, Michigan : Zondervan.

GEREFORMEERDE KERKE IN SUID-AFRIKA. 1985. Handelinge van die twee-enveertigste nasionale sinode te Potchefstroom op 8 Januarie 2000 en volgende dae. Potchefstroom : Potchefstroom Herald.

GEREFORMEERDE KERKE IN SUID-AFRIKA. 2000. Handelinge van die sewe-enveertigste nasionale sinode te Potchefstroom op 10 Januarie 2000 en volgende GKSA dae. Pretoria : V\&R Drukkery.

kyk GEREFORMEERDE KERKE IN SUID-AFRIKA

GROENEWALD, E.P. 1981. Die evangelie van Markus. Kaapstad : N.G. KerkUitgewers. 
HAMILTON, V. 1997. נַעַר. (In Vangemeren, W.A., ed. New International Dictionary of Old Testament Theology and Exegesis. Vol. 2. Grand Rapids, Michigan : Zondervan. p. 124-127.)

HENDRIKS, J. 1992. Strategiese beplanning in die gemeente. Die beginsels en praktyk van gemeentevernuwing. Kaapstad : Hugenote Uitgewers.

HENDRIKSEN, W. 1972. New Testament Commentary. Ephesians. Edinburgh : Banner of Truth.

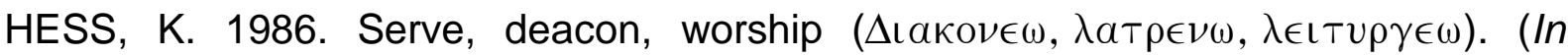
Brown, C., ed. New International Dictionary of New Testament Theology. Vol. 3. Grand Rapids, MI : Zondervan. p. 553-554.)

HEYNS, L.M. \& PIETERSE, H.J.C. 1994. Eerste treë in praktiese teologie. Pretoria : Gnosis.

JANSE VAN RENSBURG, F. 1999. Efesiërs. (In Vosloo, W. \& J. van Rensburg, F., red. Die Bybellennium eenvolumekommentaar. Die Bybel uitgelê vir eietydse toepassing. Vereeniging : CUM.)

KONVENT VAN REFORMATORIESE KERKE IN SUIDER-AFRIKA. 1999. Verklaring van die Konvent van Reformatoriese Kerke in Suider-Afrika. Woord en Daad, 367:8-9, Herfs.

LEUPOLD, H.C. 1961. Exposition of the Psalms. Grand Rapids, Michigan : Barker.

LINCOLN, A.T. 1990. Word Biblical Commentary. Volume 42. Ephesians. Dallas, Texas : Word Books.

LOUW, J.P. \& NIDA, E.A. 1988. Greek-English lexicon of the New Testament based on semantic domains. Goodwood, Cape : United Bible Societies.

LUC, A. 1997. לב. (In Vangemeren, W.A., ed. New International Dictionary of Old Testament Theology and Exegesis. Vol. 2. Grand Rapids, Michigan : Zondervan. p. 749-754.)

MENKING, S.J. 1999. Generation X: the first post-christendom generation. Quarterly Review, 19(2):153-166.

NATIONAL CONSULTATION OF CHURCHES IN SOUTH AFRICA. 1999. Declaration. Woord en Daad, 367:9-10, Herfs.

NEL, M. 1994. Gemeentebou. Halfway House : Orion.

NEL, M. 1998. Jeugbediening. 'n Inklusiewe gemeentelike benadering. Pretoria : RGN.

NEL, M. 1999. Youth ministry as Practical Theology: making a case for youth ministry as an academic discipline. Praktiese Teologie in Suid-Afrika, 14(2):23-42.

O'BRIEN, P.T. 1982. Word Biblical Commentary. Volume 44. Colossians, Philemon. Dallas, Texas : Word Books.

O'CONNELL, R.H. 1997. שִּנִ . (In Vangemeren, W.A., ed. New International Dictionary of Old Testament Theology and Exegesis. Vol. 4. Grand Rapids, Michigan : Zondervan. p. 196-198.)

RAUBENHEIMER, O. 1997. Die profiel van die jeug in Suid-Afrika. Praktiese Teologie in Suid-Afrika, 12(2):48-60.

RICHARDS, L.O. \& BREDFELDT, G.J. 1998. Creative Bible teaching. Revised and expanded. Chicago : Moody.

ROBERTS, J.H. 1990. Die brief aan die Efesiërs. Skrifuitleg vir die Bybelstudent en gemeente. Kaapstad : N.G.Kerk-Uitgewers.

SNYMAN, J. 1994. 'n Groeimodel vir jeugbediening. (In Van Rensburg, G. \& Hendriks, J., reds. Vernuwing in jeugbediening. Gemeentes aan die woord. Pretoria : Engedi. p. 138-150.)

TE VELDE, M. 1992a. Gereformeerde gemeenteopbouw 1. Een eerste koersbepaling voor een nieuw theologisch vak. Barneveld : De Vuurbraak. 
TE VELDE, M. 1992b. Gemeenteopbouw 2. Bijbelse basisprincipes voor het functionering van de christelike gemeente. Barneveld : De Vuurbaak.

THOMPSON, J.A. 1974. Tyndale Old Testament Commentaries. Deuteronomy. An introduction and commentary. London : InterVarsity.

VAN AARDE, A.G. 1991. 'n Nuwe-Testamenstiese perspektief op die kind. Hervormde Teologiese Studies, 47(3):685-715.

VAN DER WALT, J.L. 2001. Toestande wat ons kerklike voortbestaan beïnvloed - 3. Die Kerkblad, 104(3113):10-12, Aug. 1.

VAN 'T ZAND, J.D. 1995. Eenheid en verskeidenheid. 'n Model vir jeugbediening in die Gereformeerde Kerke in Suid-Afrika. Potchefstroom : PU vir CHO. (Verhandeling - Th.M.)

VAN ROOY, H. 1999. Deuteronomium. (In Vosloo, W. \& J. van Rensburg, F., red. Die Bybellennium eenvolumekommentaar. Die Bybel uitgelê vir eietydse toepassing. Vereeniging : CUM.)

WENHAM, G.J. 1994. Word Biblical Commentary. Volume 2. Genesis 16-50. Dallas, Texas: Word Books.

WRIGHT, C.J.H. 1997. אב. (In Vangemeren, W.A., ed. New International Dictionary of Old Testament Theology and Exegesis. Vol. 1. Grand Rapids, Michigan : Zondervan. p. 219-223.)

\section{Kernbegrippe:}

gemeenteopbou/gemeentebou

jeugbediening: tiener, adolessent

\section{Key concepts:}

congregation-building/building the congregation youth ministry: teenager, adolescent 